\title{
ВИЗНАЧЕННЯ ТІАНЕПТИНУ ТА МОРФІНУ В СЕЧІ ХРОМАТОГРАФІЧНИМИ МЕТОДАМИ
}

Вступ. В Україні та й у всьому світі спостерігають зростання використання психотропних речовин, які в основному впливають на центральну нервову систему. Відповідно до цього, підвищується кількість гострих отруєнь даними препаратами. 3 токсикологічної точки зору, найбільш значущими є трициклічні антидепресанти і наркотичні засоби. Причинами отруєння можуть бути застосування при суїцидах та з метою одурманення, передозування під час лікування та безконтрольне приймання препаратів для самолікування. Тому в останні роки помітно зростає науковий інтерес у токсикологічній практиці до вивчення антидепресантів та наркотичних речовин. Ситуація ускладнюється тим, що їх приймають спільно з наркотичними засобами або іншими психоактивними речовинами.

Мета дослідження - розробити методики ідентифрікації тіанептину та морфіну в біологічних рідинах (сечі) при спільній присутності методами тонкошарової хроматографрії, високоефективної рідинної хроматографії, газорідинної хроматографрії з мас-спектрометрією.

Методи дослідження. Під час дослідження використано водні розчини стандартних зразків тіанептину і морфіну; хроматографрічні системи: толуол - ацетон - 96 \% етиловий спирт - 25 \% розчин аміаку (45:45:7,5:2,5), етилацетат - метанол - 25 \% розчин аміаку (85:10:5), етанол 96 \% - метиленхлорид 25 \% розчин аміаку (57,5:40:2,5); реактиви Маркі та Драгендорфра; газовий хроматографр "Agilent 1100 2C/ MSD SL".

Результати й обговорення. ІІентифрікацію тіанептину та морфіну здійснювали за допомогою реакцій ідентифрікації, тонкошарової хроматографії. Оптимальною хроматографічною системою є етанол 96 \% метиленхлорид - 25 \% розчин аміаку (57,5:40:2,5); проявник - реактив Маркі. Встановлено параметри ідентиорікації речовин за даних умов: час утримування, спектральні співвідношення речовин, спектри поглинання в УФ-спектрах.

Висновки. Розроблено методику виявлення тіанептину та морфріну методом тонкошарової хроматограффії на пластинках марки “Sorbfil ПТСХ", методику визначення тіанептину і мороріну з використанням методу високоефрективної рідинної хроматографії, методику ідентифрікації тіанептину та морфріну методом газорідинної хроматографрії з мас-спектрометрією. Визначено оптимальні умови ізолювання тіанептину та морфіну при спільній присутності з модельних сумішей біорідини (сечі).

КЛЮЧОВІ СЛОВА: антидепресанти; тіанептин; тонкошарова хроматографрія; високоефективна рідинна хроматографія; газорідинна хроматографрія з мас-спектрометрією.

ВСТУП. Антидепресанти як медикаменти використовують найчастіше. За даними досліджень, застосування психотропних препаратів швидко збільшується в останні десятиліття. У деяких країнах світу протягом останніх кількох років використання цих засобів зросло більш ніж удвічі. Ситуація ускладнюється тим, що їх приймають спільно з наркотичними засобами або іншими психоактивними речовинами. Поряд із "класичними" трициклічними антидепресантами (амітриптилін, іміпрамін) усе частіше в практиці хіміко-токсикологічного аналізу біологічних рідин трапляються випадки немедичного застосування наркозалежними антидепресанту тіанептину (c) Н. В. Горлачук, Н. О. Зарівна, Л. М. Мосула, 2021.
(“Коаксил”, "Stablon”), який також має трициклічну структуру.

Статистичні дослідження, які стосуються зловживання тіанептином, свідчать про те, що приблизно половина всіх наркозалежних застосовувала тільки тіанептин, інші використовували тіанептин у комбінації з опіатами, каннабіоїдами, амсретамінами й іншими лікарськими засобами. Встановлено, що значний відсоток становили випадки зловживання тіанептину з опіатами [1-7].

У літературних джерелах є дані про розробку методик визначення тіанептину за допомогою методів тонкошарової хроматографії (TШX), газорідинної хроматограсрії з мас-спектрометрією (ГХ-МС), високоефрективної рідинної хро- 
матограсрії з діод-матричним детектором (BEPX) при хіміко-токсикологічних дослідженнях [8-12]. Інформації про методики спільного виявлення тіанептину й опійних алкалоїдів у біологічних об'єктах небагато.

Мета дослідження - розробити методики ідентифікації тіанептину та морфіну в біологічних рідинах (сечі) при спільній присутності методами тонкошарової хроматографії, високоефективної рідинної хроматографії, газорідинної хроматографрії з мас-спектрометрією.

МЕТОДИ ДОСЛІДЖЕННЯ. ЯК Об'єкТИ ДОслідження взято водні розчини стандартних зразків тіанептину та морфіну. Хроматограсрія в тонких шарах сорбенту знайшла широке застосування як попередній етап аналітичного скринінгу. Для ідентифікації тіанептину та морфріну за допомогою методу ТШХ використовували пластинки Силуфол УФ-254 (широкопористий силікагель Сільперл, алюмінієва основа, товщина шару 100-120 мкм, розмір - 15×15 см), Сорбфріл (силікагель СТХ-1А, фрракція - 5-17 мкм, товщина шару - 110 мкм, тип основи - ПЕТФ, розмір 10×10 см), скляні пластинки для високоефективної тонкошарової хроматограсії (ВЕТШХ, силікагель КСКГ, фрракція - 5-20 мкм, товщина шару (130 \pm 20$)$ мкм, розмір - 20×20 см). Перед використанням пластинки очищали хлороформом і висушували на повітрі, після цього активували в сушильній шафрі при $110^{\circ} \mathrm{C}$ протягом 30 хв.

РЕЗУЛЬТАТИ Й ОБГОВОРЕННЯ. ХРОМатографування проводили в камері об'ємом $1000 \mathrm{~cm}^{3}$, в яку вносили по 50 мл систем розчинників (камеру насичували протягом 40 хв). Довжина пробігу розчинників для пластинок Силуфол УФ-254 - 10 см, для інших - 7 см. На лінію старту на відстані 2 см від краю пластинки в точку діаметром 2-3 мм скляним капіляром наносили зразки тіанептину та морфіну, що містили від 0,1 до 10 мкг препаратів.

Ефективність поділу досліджуваних речовин визначали в трьох хроматографічних системах:

1) толуол - ацетон - 96 \% етиловий спирт 25 \% розчин аміаку $(45: 45: 7,5: 2,5)$ - універсальна система, яку застосовують в експрес-аналізі гострих інтоксикацій;
2) етилацетат - метанол - $25 \%$ розчин аміаку (85:10:5) - система для хроматограсрування алкалоїдів опію;

3) етанол $96 \%$ - метиленхлорид - $25 \%$ розчин аміаку $(57,5: 40: 2,5)$ - експериментально підібрана система розчинників для аналізу тіанептину.

Отримані результати хроматографування розчинів свідчать про те, що в усіх проаналізованих рухомих системах спостерігався поділ речовин. Найкращу роздільну здатність відзначали в системі № 3. Також для спільного аналізу тіанептину та морфріну можна рекомендувати систему № 2. Ці результати було підтверджено і в дослідах з модельними сумішами. Для проявлення плям тіанептину та морфріну на хроматографрічних пластинках використовували реактиви Маркі й Драгендорфа; розраховували величину Rf для кожного з речовин. Результати дослідження наведено в таблиці 1.

Подальше дослідження проводили методом газорідинної хроматографрії з мас-спектрометрією. Для аналізу використовували газовий хроматографр "Agilent 1100 2C/MSD SL" з мас-селективним детектором ("Agilent Technologies", США).

Хроматографрування виконували за розроблених для тіанептину умов аналізу [4], які також придатні для хроматографрування морфіну, однак речовини мають близькі часи утримування (час утримування: тіанептину - 25,08 хв, морфіну 25,21 хв), що може призвести до їх неесрективного розподілу в процесі аналізу біологічних об'єктів.

3 метою поліпшення хроматографування зразків ми застосували процедуру дериватизації - отримання ацетильних похідних. У процесі дослідження було встановлено, що тіанептин за даних умов пробопідготовки дериватів не утворює, час його утримування залишається сталим. У свою чергу, морфін утворює похідне морорін-3-ацетат, і час його утримування збільшується $(25,89$ хв).

Умови ГХ-МС тіанептину та морфіну при спільній присутності:

1. Пробопідготовка - отримання ацетильних похідних.

2. Колонка НP-5ms.

Таблиця 1 - Результати ідентифікації тіанептину та морфіну (n=5)

\begin{tabular}{|c|c|c|c|c|c|}
\hline \multirow[t]{2}{*}{ Речовина } & \multicolumn{3}{|c|}{$\begin{array}{c}\text { Значення Rf речовин залежності } \\
\text { від складу рухомої фрази }\end{array}$} & \multicolumn{2}{|c|}{$\begin{array}{c}\text { Колір плями та межа відкриття, } \\
\text { мкг у пробі }\end{array}$} \\
\hline & № 1 & № 2 & № 3 & реактив Маркі & реактив Драгендорфа \\
\hline Тіанептин & $0,70 \pm 0,05$ & $0,32 \pm 0,05$ & $0,49 \pm 0,05$ & $\begin{array}{c}\text { Жовтий } \\
(100 \text { мкг) }\end{array}$ & $\begin{array}{l}\text { Оранжево-коричневий } \\
\text { (50 мкг) }\end{array}$ \\
\hline Морфрін & $0,20 \pm 0,05$ & $0,22 \pm 0,05$ & $0,58 \pm 0,05$ & $\begin{array}{l}\text { Червоно-сріолетовий } \\
\text { (0,5 мкг) }\end{array}$ & $\begin{array}{c}\text { Оранжево-коричневий } \\
(0,5 \text { мкг) }\end{array}$ \\
\hline
\end{tabular}


3. Температура $-250^{\circ} \mathrm{C}$.

4. Температура колонки: до $70{ }^{\circ} \mathrm{C}$ за 5 хв; далі зі швидкістю $10^{\circ} \mathrm{C}$ за 1 хв до $300{ }^{\circ} \mathrm{C}$, витримка - 10 Хв.

5. Температура інтерфейсу $-310^{\circ} \mathrm{C}$.

6. Іонізація електронним ударом $(70 \mathrm{eV})$, сканування по повному іонному струму в діапа3оні 40-550 а.е.м.

7. Обсяг проби - 1 мкл у режимі без поділу потоку.

8. Ідентифікація - час утримування, масспектр.

Хроматограму і мас-спектри тіанептину та морфін-3-ацетату наведено на рисунку 1 , параметри ідентифрікації речовин і їх метрологічні характеристики - в таблицях 2 та 3.

При хроматограсруванні екстрактів з модельних сумішей сечі встановлено, що параметри ідентифрікації речовин (час утримування і мас- спектр) відповідають параметрам ідентифрікації в дослідах зі стандартами.

Аналіз методом BEPX дозволяє провести як якісне, так і кількісне визначення речовин.

Умови дослідження методом BEPX тіанептину та морфіну:

1. Хроматограср "Agilent 1200".

2. Колонка Eclips C18 довжиною 150 мм, діаметром 4,6 мм, розмір частинок сорбенту 5 мКМ.

3. Сорбент ProntoSIL-120-5-C18.

4. Рухома фраза - A: $\left[4 \mathrm{M} \mathrm{LiClO}_{4}-0,1 \mathrm{M}\right.$ $\left.\mathrm{HClO}_{4}\right]: \mathrm{H}_{2} \mathrm{O}(5: 95) ; 5: \mathrm{CH}_{3} \mathrm{CN}$.

5. Швидкість потоку елюенту - 100 мкл/хв.

6. Режим елюювання - градієнтний.

7. Обсяг введеної проби - 4 мкл.

8. Температура колонки $-40^{\circ} \mathrm{C}$.

Зацих хроматографічних умов спостерігають ефективний поділ тіанептину та морфіну. Іден-

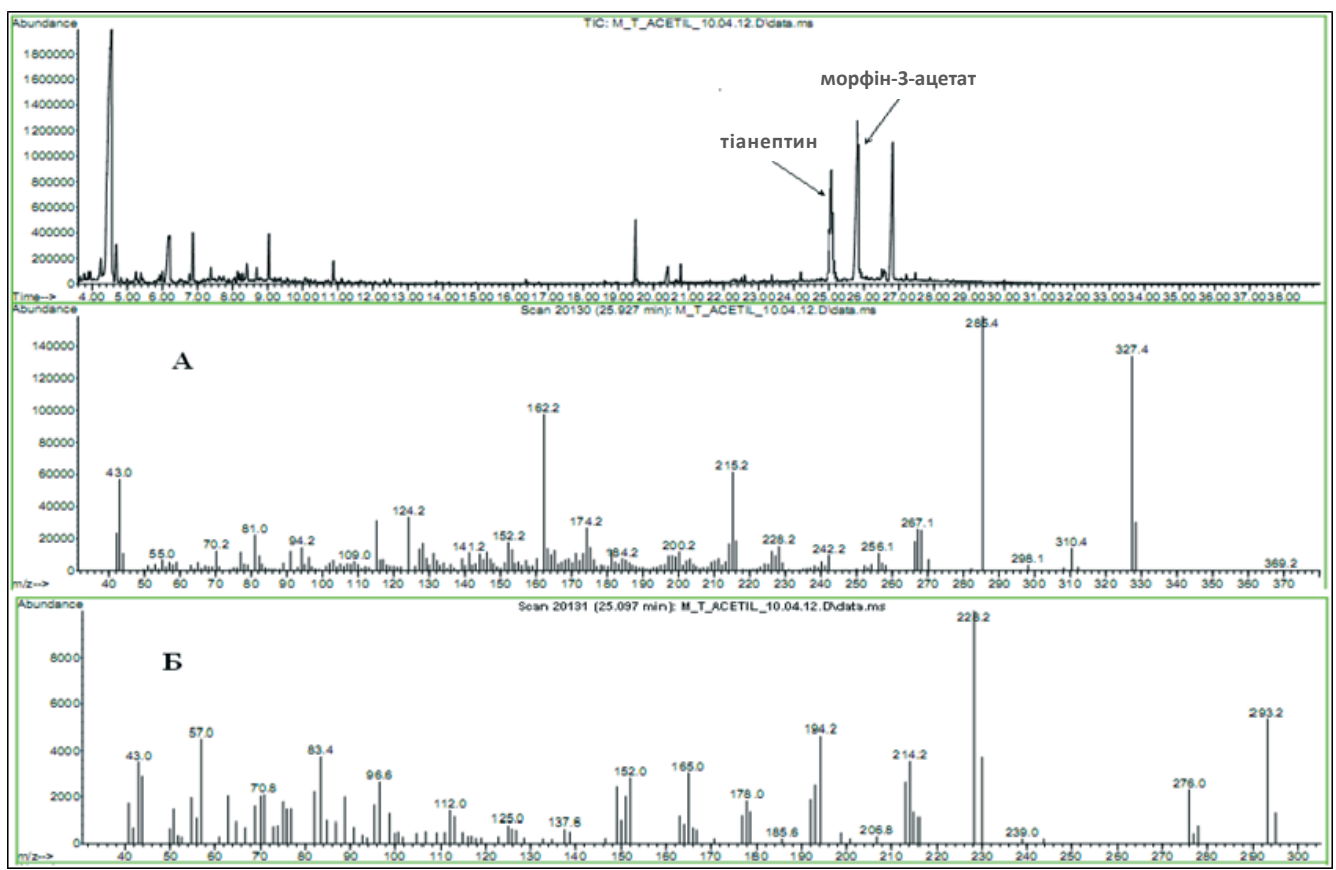

Рис. 1. Хроматограма і мас-спектри тіанептину та морфін-3-ацетату (газорідинна хроматограсрія з мас-спектрометрією): А - мас-спектр морфрін-3-ацетату; Б - мас-спектр тіанептину.

Таблиця 2 - Параметри ідентифрікації тіанептину та морфін-3-ацетату (газорідинна хроматографія 3 мас-спектрометрією, $\mathrm{n=5}$ )

\begin{tabular}{||c|c|c|}
\hline \multirow{2}{*}{ Речовина } & \multicolumn{2}{|c|}{ Параметр ідентифрікації } \\
\cline { 2 - 3 } & $\begin{array}{c}\text { час утримування } \\
\text { хв, }\end{array}$ & $\begin{array}{c}\text { характеристичні іони } \\
\text { (в порядку зменшення інтенсивності) }\end{array}$ \\
\hline Тіанептин & 25,11 & $228(100), 293(56), 194(52), 214(35), 276(28)$ \\
\hline Морфрін-3-ацетат & 25,89 & $285(100), 162(62), 327(55), 215(33), 124(30)$ \\
\hline
\end{tabular}

Таблиця 3 - Метрологічні характеристики тіанептину та морфін-3-ацетату (за часом утримування)

\begin{tabular}{||c|c|c|c|c|c||}
\hline \hline Речовина & $\bar{x}$ & SD & RSD & $\Delta x$ & $\varepsilon, \%$ \\
\hline Тіанептин & 25,11 & 0,02 & 0,09 & 0,03 & 0,11 \\
\hline Морфін-3-ацетат & 25,89 & 0,06 & 0,22 & 0,07 & 0,28 \\
\hline \hline
\end{tabular}


тисрікацію досліджуваних речовин здійснювали за абсолютним часом утримування кожного компонента, спектральним співвідношенням і УФ-спектрами, записаними безпосередньо в режимі хроматографрування.

Хроматограму й УФ-спектри поглинання тіанептину та морфіну наведено на рисунку 2, параметри ідентисрікації речовин і їх метрологічні характеристики - в таблицях 4 та 5.

Ізолювали тіанептин та морфін з модельних сумішей біологічної рідини (сечі) методом рідин- ної екстракції. Як екстрагент ми обрали хлороформ. Виходячи з показників іонізації (тіанептин pKa1 - 4,75 і рKa2 - 7,45; морфін pKa1 - 8,0 та рКа2 - 9,9), з'ясували за допомогою 10 \% розчину аміаку, що рН середовища становило 8-9, при цьому значенні $\mathrm{pH}$ середовища розчину можливо ізолювати речовини за спільної присутності. Попередньо проводили кислотний гідроліз проб сечі за допомогою концентрованої хлористоводневої кислоти для імітації руйнування кон'югатів морфіну з глюкуроновою кислотою.

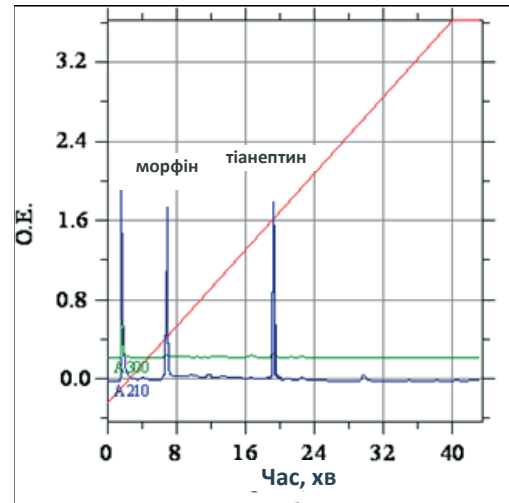

A

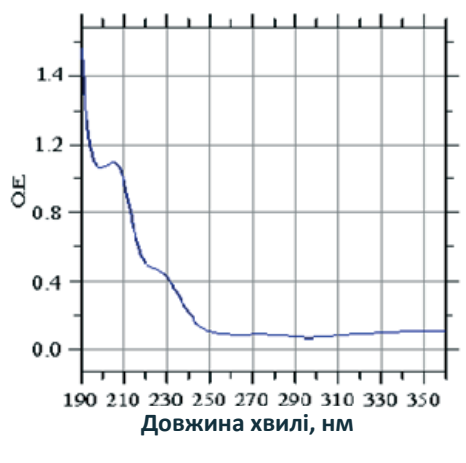

Б

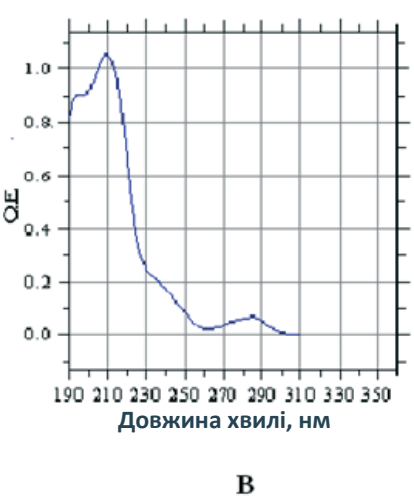

B

Рис. 2. Хроматограма і спектри поглинання тіанептину та морфіну: А - хроматограма елюювання тіанептину і морфіну (разом); Б - УФ-спектри поглинання тіанептину; В - УФ-спектри поглинання морфріну (високоесрективна рідинна хроматограсрія).

Таблица 4 - Параметри ідентифрікації тіанептину та морфіну (високоесективна рідинна хроматографрія, $\mathrm{n}=5$ )

\begin{tabular}{||c|c|c|c|c|c|c|c||}
\hline \multirow{2}{*}{ Речовина } & Час утримування, & \multicolumn{6}{|c||}{ Спектральні відношення, $\mathrm{R}=\mathrm{S}_{1} / \mathrm{S}_{210 \text { нм }}$} \\
\cline { 3 - 8 } & хв & 220 & 230 & 240 & 50 & 260 & 280 \\
\hline Tіанептин & 19,10 & 0,494 & 0,395 & 0,180 & 0,060 & 0,044 & 0,042 \\
\hline Морфрін & 6,43 & 0,589 & 0,227 & 0,156 & 0,071 & 0,016 & 0,052 \\
\hline
\end{tabular}

Таблиця 5 - Метрологічні характеристики тіанептину та морфіну (за часом утримування)

\begin{tabular}{||l|c|c|c|c|c||}
\hline \multicolumn{1}{|c|}{ Речовина } & $\overline{\mathrm{X}}$ & $\mathrm{SD}$ & $\mathrm{RSD}$ & $\Delta \mathrm{x}$ & $\varepsilon, \%$ \\
\hline Тіанептин & 19,10 & 0,08 & 0,38 & 0,10 & 0,47 \\
\hline Морфрін & 6,43 & 0,09 & 1,40 & 0,11 & 1,74 \\
\hline
\end{tabular}

ВИСНОВКИ. 1. Розроблено методику виявлення тіанептину та морфіну методом тонкошарової хроматографрії на пластинках марки "Sorbfil птСХ". Оптимальноює хроматографрічна система етанол $96 \%$ - метиленхлорид - 25 \% розчин аміаку (57,5:40:2,5); проявник - реактив Маркі.

2. Розроблено методику визначення тіанептину і морфіну з використанням методу високоефективної рідинної хроматографії. Встановлено параметри ідентифікації речовин у таких умовах: час утримування, спектральні співвідношення речовин, спектри поглинання в УФ-спектрах.

3. Розроблено методику ідентифікації тіанептину та морфіну методом газорідинної хроматограсрії з мас-спектрометрією. Пробопідготов- ка - отримання ацетильних похідних морфріну. Встановлено параметри ідентифікації речовин у запропонованих умовах: час утримування, основні характеристичні іони мас-спектра.

4. Визначено оптимальні умови ізолювання тіанептину і морфіну при спільній присутності 3 модельних сумішей біорідини (сечі). Умови екстракції: кислотний гідроліз сечі, pH середовища розчину - 8-9, екстрагент - хлорофрорм.

5. Розроблені методики визначення апробовані в дослідах з модельними сумішами біологічних рідин (сеча). Встановлено, що запропоновані методики дозволяють визначити тіанептин та морфін при спільній присутності в біологічній рідині при хіміко-токсикологічних дослідженнях. 


\section{СПИСОК ЛІТЕРАТУРИ}

1. Fatal intoxicationwith tianeptine (Stablon) / P. Proenca, H. Teixeira, J. Pinheiro [et al.] // Forensis Sci. Int. 2018. - No. 170. - P. 200-203.

2. Kisa C. Is it possible to be dependent to tianeptine an antidepressant / C. Kisa, D. Bubul, E. Goka // Prog. Neuropsychopharmacol Biol. Psychiatry - 2017. No. 6. - P. 776-778.

3. Богинская Д. Д. Зависимость от тианептина (коаксила) / Д. Д. Богинская, С. О. Мохначев // Наркология. - 2002. - № 3. - С. 32-42.

4. Богинская Д. Д. Клиническая картина злоупотребления тианептином (коаксилом) / Д. Д. Богинская, С. О. Мохначев // Вопросы наркологии : материалы консреренции. - 2005. - № 4. - С. 46-47.

5. Мохначев С. О. Анализ 40 случаев злоупотребления тианептином (коаксилом) / С. О. Мохначев, М. Л. Рохлина, Д. Д. Богинская // Вопросы наркологии. - 2008. - № 5. - С. 102-107.

6. Demotes-Mainard F. Pharmacokinetics of the antidepressant tianeptine at steady state in the elderly / F. Demotes-Mainard, P. Qalley, C. Salvadori // J. Clin. Pharmacol. - 2019. - 31, No. 2. - P. 174-178.

7. Dalery J. Efficacy of tianeptine versus placebo in the long-term treatment of unipolar major recurrent de- pression / J. Dalery, C. De Bodinat // Encephalon. 2015. - No. 23. - P. 56-62

8. Kirchherr H. Quantitative determination of fortyeight antidepressants and antipsychotics in human serum by HPLC tandem mass spectrometry: a multilevel, single sample approach / H. Kirchherr, W. Kuhn-Velten // J. Chromatogr. B. Analyt. Teghnol. - 2016. - 20, No. 7. P. 100-113.

9. Will S. Comparison of electron and chemical ionization modes by validation of a quantitative gas chromatographic - mass spectrometric assay of new generation antidepressants and their active metabolites in plasma / S. Will, H. Neels // J. Chromatigr. A. - 2017. 1176, No. 1. - P. 236-242.

10. Novakova E. Detection of new antidepressive agents using thin - layer chromatography / E. Novakova // Soud Lek. - 2014. - No. 1 - P. 2-6.

11. Гончарук Н. В. Застосування методу хроматографрії в тонкому шарі сорбенту для ідентифрікації тіанептину / Н. В. Гончарук, І. Й. Галькевич // Фармац. часоп. - 2007. - № 3. - С. 37-38.

12. Горлачук Н. В. Хромато-мас-спектрометричний аналіз тіанептину в сечі / Н. В. Горлачук, Л. М. Мосула, Н. О. Зарівна // Мед. та клін. хімія. - 2018. - 20, № 4 (77). - С. 146-152.

\section{REFERENCES}

1. Proenca, P., Teixeira, H., Pinheiro, J., Monsanto, P., Vieira, D. (2018). Fatal intoxicationwith tianeptine (Stablon). Forensis Sci. Int., 170, 200-203.

2. Kisa, C., Bubul, D., \& Goka, E. (2017). Is it possible to be dependent to tianeptine an antidepressant. Prog. Neuropsychopharmacol. Biol. Psychiatry, 6, 776-778.

3. Bohynska, D.D., \& Mokhnachev, S.O. (2002). Zavisimost ot tyaneptyna [Tianeptine addiction]. Narkologiya - Narcology, 3, 32-42 [in Russian].

4. Bohynskaia, D.D., \& Mokhnachev, S.O. (2005). Klinicheskaya kartina zloupotrebleniya tyaneptynom (koaksylom) [The clinical picture of tianeptine (coaxil) abuse]. Voprosy narkologii: materialy konferentsii Narcology Issues: Conference Proceedings, 4, 46-47 [in Russian].

5. Mokhnachev, S.O., Rokhlyna, M.L., \& Bohynskaia, D.D. (2008). Analiz 40 sluchaev zloupotrebleniya tyaneptynom (koaksylom) [Analysis of 40 cases of abuse of tianeptine (coaxil)]. Voprosy narkologii - Narcology Issues, 5, 102-107 [in Russian].

6. Demotes-Mainard, F., Qalley, P., Salvadori, C. (2019). Pharmacokinetics of the antidepressant tianeptine at steady state in the elderly .J Clin Pharmacol., 31 (2), 174-178.

7. Dalery, J., \& De Bodinat, C. (2015) Efficacy of tianeptine versus placebo in the long-term treatment of unipolar major recurrent depression Encephalon., 23, 56-62.

8. Kirchherr, H., Kuhn-Velten, W. (2016) Quantitative determination of forty-eight antidepressants and antipsychotiss in human serum by HPLC tandem mass spectrometry: a multilevel, single - sample approach J. Chromatogr. B. Analyt. Teghnol., 20 (7), 100-113.

9. Will, S., \& Neels, H.(2017). Comparison of electron and shemical ionization modes by validation of a quantitative gas chromatographic - mass spectrometris assay of new generation antidepressants and their active metabolites in plasma J. Chromatigr. A.1176 (1), 236-242.

10. Novakova, E. (2014). Detection of new antidepressive agents using thin - layer chromatography. Soud Lek., 1, 2-6.

11. Honcharuk, N.V., \& Halkevych, I.I. ( 2007). Zastosuvannia metodu khromatohrafii $v$ tonkomu shari sorbentu dlia identyfikatsii tianeptynu [Application of the method of chromatography in a thin layer of sorbent to identify tianeptine]. Farmatsevtychnyi chasopys - Pharmaceutical Review, 3, 37-38 [in Ukrainian].

12. Horlachuk, N.V., Mosula, L.M., \& Zarivna, N.O. (2018). Khromato-mas-spektrometrychnyi analiz tianeptynu v sechi [Chromato-mass spectrometric analysis of tianeptine in urine]. Medychna ta klinichna khimiia Medical and Clinical Chemistry, 4, 146-152 [in Ukrainian]. 


\section{DETECTION OF TIANEPTINE AND MORPHINE IN URINE BY CHROMATOGRAPHIC METHODS}

\section{Summary}

Introduction. In Ukraine and around the world there is an increase in the use of psychotropic substances, which mainly affect the central nervous system. Accordingly, the number of acute poisonings by these drugs increases. From a toxicological point of view, tricyclic antidepressants and narcotics are the most important. Causes of poisoning can be the use of suicide and intoxication, overdose during treatment and uncontrolled use of drugs due to selfmedication. In recent years, there has been a growing scientific interest in toxicological practice in the study of antidepressants and drugs. The situation is complicated by their joint use with drugs or other psychoactive substances.

The aim of the study - to develop methods for the identification of tianeptine and morphine in biological fluids (urine) in the joint presence of thin layer chromatography (TLC), high performance liquid chromatography (HPLC), mass spectrometry (MS).

Research Methods. Aqueous solutions of standard samples of tianeptine and morphine; chromatographic systems: toluene-acetone-96 \% ethyl alcohol-25\% ammonia solution (45: 45: 7,5: 2,5), ethyl acetate-methanol-25\% ammonia solution (85: 10: 5), ethanol-methylene chloride-25\% ammonia solution (57.5: 40: 2.5); Marki and Dragendorf reagents; gas chromatograph Agilent $11002 \mathrm{C} / \mathrm{MSD}$ SL were used during the study.

Results and Discussion. Identification of tianeptine and morphine was performed by identification reactions, thin layer chromatography (TLC). The optimal chromatographic system is ethanol $96 \%$ : methylene chloride: $25 \%$ ammonia solution (57.5: 40: 2.5); developer - Mark's reagent. The parameters of substance identification in these conditions are established: retention time, spectral ratios of substances, absorption spectra in UV spectra.

Conclusion. A method for detecting tianeptine and morphine by thin-layer chromatography on Sorbfil PTSH plates, a method for determining tianeptine and morphine using high-performance liquid chromatography, a method for identifying tianeptine and morphine by mass spectrometry were developed. The optimal conditions for the isolation of tianeptine and morphine in the joint presence of model mixtures of bioliquid (urine) were determined.

KEY WORDS: antidepressants; tianeptine; chemical and toxicological research; thin layer chromatography; high performance liquid chromatography; chromato-mass spectrometry.

Отримано 06.09.21

Адреса для листування: Н. В. Горлачук, Тернопільський національний медичний університет імені І. Я. Горбачевського МОз України, майдан Волі, 1, Тернопіль, 46001, Україна, e-mail: horlachuk@tdmu.edu.ua. 